\title{
A Ute, Not a Land Cruiser: Publishing Reading the Country
}

\section{Ray Coffey}

I begin with a qualification. Much of what follows is based on memory of over thirty years ago.

The beginning for Fremantle Arts Centre Press (FACP) was in 1982 when Stephen sidled up to me at Adelaide Writers' Week and said, 'Pssst, do you want to see a manuscript'. Anyone in publishing knows that this could now go anywhere or nowhere, or be about anything, perhaps even everything, or about nothing.

Stephen went on to explain that the text was a collection of stories by an Aboriginal man from the west Kimberley, presented as a form of direct transcription from the oral source.

This was of immediate interest. First, because the manuscript was not one of the usual approaches at that time: 'as told to' or rewritten to fit European forms. Approaches that so often flatten out, dumb down and misrepresent the original material. Growing up in Australia in the 1950s, 1960s and 1970 most of us had been exposed to these tired and unimaginatively presented 'Aboriginal stories' or 'Aboriginal Myths' or 'Dreamtime stories'. The possibility that here was a MS which had reimagined the way such material could be approached and presented spoke directly to our own instincts and desires at the fledgling FACP.

FACP began in 1976 as a not-for-profit literary publishing house - initially focused on poetry and literary fiction. We were established with the purpose of not only editing and publishing but also of supporting and assisting the development of Western Australian writers and writing. This nurturing role, in which FACP has always been supported by a modest grant from the WA Department for the Arts, has proved a 
cornerstone of its success and survival. When we started, an article appeared in the local press that included a comment by a critic suggesting that the venture was doomed because 'they'll soon run out of writers'.

In some ways, because we were young and very inexperienced as publishers, we just did not recognise the possibilities of failure that loomed about us. We were engaged by the exciting possibilities of our undertaking, not by the possible limitations. We just kept thinking, imagining and moving. Of course, they were perhaps kindlier, gentler times for such enterprises. (But that's for another story.)

Although FACP began life as a literary publisher, we rapidly looked to expand into other areas of publication. The Press grew out of the Fremantle Arts Centre, an organisation established at the start of the 1970 s to promote the visual arts and crafts in Western Australia through exhibition and education. Similarly, a publishing program was seen as the best way to promote, to the widest possible audience, writers and writing from Western Australia. Our association with the Arts Centre and the visual arts was initially expressed through the use of works of art on the covers of our books - and often inside them as well-but within a few years we also began publishing our first art monographs.

The manuscript Stephen submitted also appealed to us as literary publishers. For us, the use of language and awareness of the possibilities of language, were of primary importance. So when we looked at the MS, which was to be published in 1983 as Gularabulu: Stories from the West Kimberley, ${ }^{1}$ we were struck by how the immediacy, liveliness and authenticity of the oral language was so successfully recreated on the page.

Paddy Roe and Stephen Muecke's Gularabulu texts were indeed a radical departure from how oral narratives had been previously presented. The on-page presentation - as a kind of cross between poetry and theatre - recreated, as near as we had come across, the dynamics of the spoken word, of the storytelling experience. Re-reading the book in preparing this talk, I am still excited by the immediacy of the voice, the sound 
of the voice; I am often startled, in a way that poetry can startle, by an unexpected usage, a novel coinage, an original (for me) way of seeing. And I am again admiring of Muecke's lightness of touch and his editorial integrity.

The third reason we were interested in the possibilities of the Gularabulu manuscript was that the stories were from an Aboriginal person - they came from outside the mainstream, outside the grand narrative of Australian cultural and historical experience. They helped expand our understanding and knowledge of what it means to be in this country, of what it means to be human.

As has been widely noted, through the 1970 s we saw an increasing interest in Australian stories and experience, initially through theatre, film, television and the visual arts. This interest arose and grew not only among writers, artists, filmmakers and intellectuals but also with Australian readers and audiences. At FACP I think we did see ourselves as part of a general political and cultural awakening in Australia; we felt we were grasping an opportunity to make up for the lost ground of the politically, socially and culturally conservative 1950 s and 1960 . They were exciting times - a spirit of '68, if you will-with a lot to do and a will to do it.

By the late 1970s, with the approach of Western Australia's 1979 sesquicentennial, to be followed by Australia's bicentennial, at Fremantle we decided to develop a non-fiction list with a primary focus on stories by and about ordinary people and their experiences. Influenced by the Hackney Project in the then working-class borough of that name in northeast London, which sought to gather and publish the stories of the people and the workplaces of the local area, we successfully applied for a grant from a state government sesquicentennial fund to establish the Community Publishing Project. Through this project we actively sought manuscripts from non-writers, from ordinary working men and women, from people from the diverse range of ethnic backgrounds that make up our community. It is perhaps hard to imagine now when we are bombarded by a book or television program on seemingly every person and their dog and the dog's stylist, that until the 1980 biography and memoir was overwhelmingly the preserve of politicians, military men and the squattocracy. 
The three or four years of the Community Publishing Project produced a dozen, or so, mostly small print-run, modest publications. Several were successful enough to go to a second and third printing and to sell reasonable numbers outside their immediate communities.

But the other success from the project was that it enabled FACP to put up its shingle in the wider, non-literary community as a publishing house that supported the development of writers with a story to tell, irrespective of background or experience. As a result, I believe, many people who may not have otherwise done so set out to write down their story, or a relative's story, or a local history, or they dusted off something put away in a bottom drawer that they never thought anyone would be interested in.

Over the years Fremantle has successfully published a great many of these kinds of stories, taking local people, local experiences, to the world. In particular, A Fortunate Life by A. B. Facey and Sally Morgan's My Place ${ }^{2}$ have become two of the most successful books in Australian publishing history. Interestingly, Facey's manuscript evolved from a series of dusty notebooks in the back of a wardrobe until one of his daughters pulled them out when she learnt of our community publishing program. 'I was wondering if I could get a few copies printed up for the family', she said when she brought in a rough typescript she had made from the notebooks.

And later with My Place, Sally Morgan approached me with the idea for her book as a result of the success of A Fortunate Life. I guess A Fortunate Life, having been published to immediate national success in 1981, may have also been a factor that influenced Stephen to show us Gularabulu.

So this collection of Paddy Roe's stories also interested us for the unique way in which it expanded the repertoire of stories, indeed histories, told about Australia, and because it represented a voice not usually heard by most of us, and certainly not one usually found between the covers of a book. In its own modest way Gularabulu proved to be a publishing success, attracting very good reviews and going to a reprinttravelling from a small corner of north-west Western Australia into libraries, schools and homes throughout Australia and overseas. Not long after the book first appeared, the historian 
and poet, Eric Rolls (author of A Million Wild Acres 3 ), told me that he not only found it a beautiful book to read, but thought it among the most culturally important books to have been published in Australia.

Of course, the publication of Gularabulu was for us, and presumably for Paddy and Stephen, a seed for something altogether more ambitious and more radical.

The editing, production and publication of Gularabulu not only introduced me to Paddy and Stephen but also Krim Benterrack. Those familiar with the earlier book will know that the cover features a splendidly appropriate Benterrack painting of a spring in Paddy Roe's country.

I believe it was during work on Gularabulu, or perhaps just after publication, that Stephen and Krim began to talk with me about an idea for another, more ambitious book. Another book with Paddy Roe's country and his stories and knowledge at its centre, but which would include a range of other ideas, visions and knowledges in response to this place called Roebuck Plains. A book about the local, about the specifics of $a$ place, but which would lead to questions about how we might make sense of all the places in which we live and pass through.

The idea of such a book appealed to us at Fremantle Press, not the least because it promised to explore and articulate a number of issues and ideas we were seeking to address and promote as a publisher. Language, story, the visual arts, cultural exploration and exchange, multidisciplinary approaches to knowledge and experience, new ways of seeing and expressing - these were all things we were drawn to.

So, too, 'place'. It is often suggested that it is geographic isolation - a remote corner of the globe, locked between desert and ocean - that seems to have given Western Australians a particular preoccupation with the idea of place. In the 1970 s questions regarding a 'sense of place' received a particular intellectual focus, with seminars, papers and books engaging with the issue. (As most of you will be aware, I am sure, in recent years writer Kim Scott has written and spoken eloquently, from an Indigenous perspective, on this preoccupation as being an expression of European-Australian insecurity.)

Although, to various degrees, we at FACP had engaged with those exchanges on the meaning and value of place, our 
primary focus was on how you might write and publish from and of the particular, from and of the local, yet do so in a way that had much wider meaning and relevance. Apart from an intellectual and emotional desire to do this, there was also an economic imperative that it inform our work. This concern about how the particular might move outwards informed our editing, design and production, marketing and promotion.

But a critical aspect of this is to be able to speak back to the local while engaging the wider community. Despite awareness, attention and effort, success in this is always variable. As I mentioned earlier, Gularabulu was successful critically and in finding a readership but, ironically, as you will all know, its readership was overwhelmingly non-Indigenous and primarily literary and academic. This remains an issue with which we all continue to grapple.

So Reading the Country began as a set of ideas and desires shared between Paddy, Stephen and Krim, as outlined in the opening texts of the published book, which were then shared with me as publisher and editor. From first discussions, within the limitations of a small publisher with no money and few resources, I believe that we were supportive of the book. Certainly we would have been very positive to the idea of a book built from a wide range of materials - Paddy's stories and knowledge side by side with Krim's paintings, Stephen's essays, commentary and photographs, Butcher Joe Nangan's songs, and interviews and other fragments and pieces from history and other disciplines - with the journey through the country of Roebuck Plains to unify it all.

The other attraction for me was that Stephen, Krim and Paddy embraced, indeed valued highly, input from a publisher's editor in the process; from teasing out and developing ideas and possibilities, to building and shaping the final book. They understood that the ideal relationship between author and publisher is a collaborative partnership. Because of the richness of this particular collaborative experience, as well as the book's content, Reading the Country has remained a highlight of my long editing and publishing career. ${ }^{4}$ 
An idea of Stephen's struck me early in the editorial process and became a sort of guide. At the beginning of the book, he refers to I.A. Richard's notion that 'a book is a machine for thinking with'. Winding down the window and sticking out a sunburnt elbow, Stephen expands, 'it can pick you up in one thinking spot and take you to another one. It's like a ute.'

So, I saw that this book was to be a working vehicle, loaded with a lot of useful stuff, packed in a particular order at the outset, but which anyone can draw from however they wish, according to interest and need.

Certainly a loose structure was intended which could shape the general accumulation of knowledge, experience and ideas as a reader travels through, but we knew that there were many ways of travelling and of reading. So, while the journey of the book does broadly follow a series of journeys across the physical landscape, which we can plot on Krim's painting/map at the beginning of the book, it is also a journey into ideas and experience which, as we know, plot their own course. Thoughts can take you anywhere. A story or idea in an essay can lead to a song, which can jump you back to a map, or forward to a painting, then to another story.

Thinking about the book in this way from the outset enabled us to build into the text some guidance and signposts for readers as to how they might read the book, so they might locate themselves as they move through. This is about establishing and maintaining trust in the text. Michael Ondaatje in his novel In the Skin of the Lion writes:

The first sentence of every novel should be:

'Trust me, this will take time but there is order here, very faint, very human.' Meander if you want to get to town. ${ }^{5}$

Helping to ensure that trust is established and maintained between text and reader could be a way of thinking about the role of an editor of any book.

So to editing. With Reading the Country, as with any book, my first and most basic role was to check the dotting of 'i's' and crossing of ' $t$ 's, the technical stuff-spelling, punctuation, syntax, grammar. All the stuff that should never be noticed, 
that should not distract the reader from the purpose of engaging with the content of a book.

(Sadly, despite best efforts errors can get through. For example, I noted when preparing this talk and reading the 1996 revised edition of the book that many internal page references are out by a page or two. It certainly tests the trust when as early as page 15 , paragraph 1 , we are directed to 'see map page 59' only to find the map on page 61. Clearly, this was an error that crept in when the pages were reformatted for the new edition and not picked up in proofreading. I apologise for this.)

The other essential role of an editor is to try to ensure consistency and clarity. That Nargananan is spelt that way throughout (although Krim's map/painting proved to be a law unto itself), that something on page 100 does not disagree, or appear to disagree with something earlier, to identify and seek to resolve possible obscurities or lack of clarity, and so forth. An editor has to imagine the future readers and be a first reader on their behalf; an editor will therefore try to approach the text not only with their own knowledge, expertise and limitations, but with those of the imagined readers.

From memory, Stephen, who did the main author liaising with me, sent the various texts through to me for feedback in a number of batches. I think Stephen pretty much built his essays around Paddy's stories and dialogues, so sometimes I'd get a story and associated essay together and other times a story would have a note indicating intended content of an essay to come.

Quite early, when talking about the possible essays Stephen was planning, I remember thinking of them and referring to them as meditations-discourses expressing considered thoughts on a subject - as, for me, this seemed to reflect a tone he was after. I know that maintaining this kind of tone informed my reading and editorial comments and suggestions back to Stephen on the various pieces.

There are only a few specifics that I recall from working on the essays. My recollection is that the introductory piece 'Nomadic Writing', or at least the first half of it arose, at least in part, from the early discussion and decision that the literal journey across the plains would provide the book with its loose 
narrative trajectory. At some point I think I suggested that the actual process of creating the book-which was emerging in the stories, essays, and so on as they appeared-might be foregrounded more, beginning with a description of Paddy, Stephen and Krim gathering together in Broome in preparation for the journey ahead. A traveller's tale; a simple publisher's device to ease a reader into the journey, and then to link the various elements of the book.

It was Stephen, too, who took most of the photographs, or provided them from other sources. He was keen that by and large we should try to avoid captions. So, because most of the images directly illustrated Paddy's texts or Stephen's essays, I came up with the editorial/design solution to, as far as possible, treat them like paragraphs within the text. Thus, apart from placing them as exactly as possible before or after the passages they relate too, most have been blocked out to the text margins and trimmed down top or bottom to sit within the text just like another paragraph. Apart from negating the need for captions, placed in this way they, relatively unobtrusively, extend the texts and reading experience.

There was, I think, only one major editorial issue with the transcriptions of Paddy's words. Initially all these texts had been transcribed and presented in the same form, in the manner of the stories in Gularabulu. Lines were broken and turned to the next line at pauses, with the varying lengths of the pauses represented by dashes at the ends of lines. As with the earlier book, with the new stories this radically new form of presenting such material worked brilliantly. But half Paddy's texts in Reading the Country are not stories, but more of the nature of dialogues with Stephen, Krim and/or Butcher Joe, or monologues imparting information and knowledge as he travelled across the landscape. I didn't feel it worked as well to present these in the same form as the stories. For me, presenting them in the same way as the stories perhaps detracted from the integrity of the stories. So I suggested to Stephen we look at giving the non-story texts their own form. After pushing around a few ideas and tinkering with formats we came up with the variation now in the book. Looking at it now, I think it works pretty well, signalling to the reader a different form, context and tone. A different reading. 
With Krim's paintings my 'editorial' work was minimal. Apart from ensuring we had all the correct technical stuff - title, date, medium - I remember suggesting a map/ painting for the endpapers. But I think even this Krim may have thought of earlier. Krim left the cover to last and very late in the process, so we could provide him with final format and design specifications. The stunning piece he produced was all we could wish for. For a publisher the perfect cover, one that demanded to be looked at, picked up, paid for and given a good home. Sometimes a ute can look as spiffy as a inner city Land Cruiser, but still remain a solid, hard-working carry-all, not frightened to go off the bitumen.

Another critical editorial/publishing issue with the paintings was their placement. An important issue for publishers is the cost of colour printing and, to minimise costs, colour is often grouped together in as few sections of the book as possible. I was keen from the start to integrate the paintings throughout the book; treat them in the same way as the book's various other voices - speaking with, responding to, counterpointing or reinforcing each other. So a publishing decision was made early that for the integrity of the book we would wear the not inconsiderable extra cost, take the extra economic risk, and place the paintings throughout the book.

An aside. Interestingly, the reason we were able to take this economic risk is another thing for which we might thank A.B. Facey and A Fortunate Life. As I've said, that book was a great success. But one that almost killed us. Pre-publication sales were such that by the release date we had had to press the reprint button, and this run too had effectively sold on release, so a loan was required for another printing. And still it went on. The problem of success like this for a small organisation with no capital is that print bills were due at thirty days, but bookshops paid at sixty or ninety days. At the time we were working on Reading the Country Penguin Australia had offered to buy the rights to A Fortunate Life, but we said no, and instead offered to lease rights for an advance and a percentage of Penguin's sales. The counter offer was accepted. So financially, apart from anything else, this enabled us to present the Reading the Country paintings to best advantage. 
To continue this aside for a moment, the great success of A Fortunate Life was such that Penguin were quickly back negotiating an extension of the lease. As part of that extension agreement, we negotiated a national distribution arrangement with Penguin for all our books - we became the first publisher outside their own stable to do so. Thus, Reading the Country was among the first of our books to benefit from this arrangement, increasing national distribution and sales considerably above what might have been expected for a 'difficult' book produced by what was, at the time, a tiny publishing house on the wrong side of the country.

We are asked about the decision by Fremantle Press thirty years ago to publish a radical text like Reading the Country.

Essentially, a simple answer is that we did not think of the book in this way. Of course we knew that on a number of levels it was and would be seen to be radical. But for us, radical was not an issue-at least, not a negative or limiting one. At the time, in some respects setting up a small independent Australian publishing house was fairly radical, publishing contemporary Australian fiction and art was fairly radical. You did not have to go back far to when teaching Australian literature in our universities was radical (the early 1970s, perhaps?), or the idea of our own film industry, or when wearing jeans or women drinking in bars was radical. In the 1970 in some parts of Australia the idea of Aboriginal people living in towns rather than on reserves was still radical. So, as suggested earlier, the context is that we had been through a decade or so of some quite radical political, social and cultural shifts in Australia.

As also indicated earlier, Fremantle Arts Centre Press began as a publisher of contemporary Australian literary fiction and poetry and art monographs, and as we know, in Australia through the 1970 s relatively radical explorations of these forms and a range of largely hitherto neglected issues and subjects began to be made by a number of our writers and artists. Developments we readily embraced at Fremantle. Indeed, 'radical', 'difference', 'groundbreaking' were all things we were naturally attracted towards. 
This is not to diminish the importance and impact of Reading the Country, it's just to say that in the context in which we had grown, as individuals and as an organisation, radical was not a dirty word.

In 1980s Australia another way in which the book was considered radical, and perhaps controversial, was how Stephen's texts drew strongly upon what was seen then as radical cultural and literary theory. Indeed, in Australia it was quite widely dismissed either as a silly and incomprehensible French fad or vehemently attacked as a dangerous threat to life as we know it.

My memory is that the ideas of post-modernism, -structuralism and -colonialism and the work of the likes of Barthes, Derrida and Foucault really only staggered into Perth in the latter half of the 1970s, and by the early 1980 s were upsetting the neighbour's dogs. I must confess, coming to this writing cold I did not always find the language particularly easy, but along with my editorial colleague at Fremantle Press I was readily sympathetic and attracted to many of the ideas, perspectives and tools for thinking that it provided.

So again, this theoretical aspect of Reading the Country, although perhaps considered radical in some quarters at the time, found an interested ear at FACP. What excited us most, I think, was Muecke's ability to take these ideas out of the abstract and onto the ground so we could see how they moved. And this was one of the radical aspects of Reading the Country in Australia in 1984: showing how Theory relates to what is in front of us; how it is a tool for thinking and talking in new and extremely valuable ways about Aboriginal culture and experience, about landscape, and about how we might make sense of our experiences of all the places in which we live.

The legacy of Reading the Country for Fremantle Arts Centre Press has been significant. And, although hard to quantify, I think the book's appearance also played a role in a shift among some other Australian publishing houses, for a time at least, towards including more adventurous non-fiction titles on their lists. 
At Fremantle, Reading the Country and Gularabulu were the beginning of what became a very active and successful program of publishing Aboriginal writers and writing on Indigenous issues and experience. A long list that includes fiction, poetry, memoir, art books, children's books, political, social and cultural analysis; that includes the international bestseller and award-winning My Place by Sally Morgan, Stephen Kinnane's multi-award-winning Shadowlines, the work of duel Miles Franklin award-winning novelist Kim Scott, and Anna Haebich's major, multi-award-winning history of the stolen generations, Broken Circles: Fragmenting Indigenous Families 1800-2000. 6

I think that working on Reading the Country so early in our career as publishers strongly reinforced our views that publishing and editing is a collaborative partnership to the extent that it became a cornerstone of our practice as publishers. We also learnt much from Stephen Muecke and Paddy Roe's editor-author relationship. I think that the respect and sensitivity displayed in both Reading the Country and Gularabulu helped inform the way we approached our editorial relationships with the large list of work we developed with inexperienced writers and informants, Indigenous and non-indigenous.

The experience of publishing Reading the Country also helped reinforce our view that a large part of our role as independent, not-for-profit publishers was to be prepared to take risks with writers and writing that others were unlikely to. We successfully managed this for many years by developing a more commercial, mainstream list to not only, and necessarily, financially sustain the organisation, but to help cross subsidise a program of more adventurous and risky titles.

For the thirty years I was at Fremantle Arts Centre Press, Reading the Country was always seen by us and represented to others as one of the cornerstones of our achievement and of who we were as publishers. This is not just because of the role we played in producing such a positive exemplar of how we might find practical ways to engage and exchange with Indigenous history, experience and knowledge. It is also because for us the book was a touchstone for the active role that publishers, along with other cultural institutions and the academies, should play in the general sharing of knowledges 


\section{and the discussion and exchange of political, social and cultural ideas in Australia.}

\section{Notes}

1 Paddy Roe, Gularabulu: Stories from the West Kimberley, ed. Stephen Muecke, Fremantle Arts Centre Press, Fremantle, 1983.

2 A.B. Facey, A Fortunate Life, Fremantle Arts Centre Press, Fremantle, 1981; Sally Morgan, My Place, Fremantle Arts Centre Press, Fremantle, 1987.

3 Eric Rolls, A Million Wild Acres: 200 Years of Man and an Australian Forest, Nelson, Melbourne, 1981.

4 Krim Benterrak, Stephen Muecke and Paddy Roe, Reading the Country: Introduction to Nomadology, Fremantle Arts Centre Press, Fremantle, 1984.

5 Michael Ondaatjie, In the Skin of the Lion, Picador, London, 1988, p. 146.

6 Stephen Kinnane, Shadowlines, Fremantle Arts Centre Press, Fremantle, 2003; Kim Scott, True Country, Fremantle Arts Centre Press, Fremantle, 1993; Kim Scott, Benang: From the Heart, Fremantle Arts Centre Press, Fremantle, 1999; Anna Haebich, Broken Circles: Fragmenting Indigenous Families 180o-200o, Fremantle Arts Centre Press, Fremantle, 2000. 